\title{
Endogenous U2.U5.U6 snRNA complexes in S. pombe are intron lariat spliceosomes
}

\author{
WEIJUN CHEN, ${ }^{1,2}$ HENNADY P. SHULHA, ${ }^{2,3}$ AMI ASHAR-PATEL, ${ }^{1,2}$ JING YAN, ${ }^{1,2}$ KARIN M. GREEN, \\ CHARLES C. QUERY, ${ }^{5}$ NICK RHIND, ${ }^{2}$ ZHIPING WENG, $^{2,3}$ and MELISSA J. MOORE ${ }^{1,2,6}$ \\ ${ }^{1}$ Howard Hughes Medical Institute, ${ }^{2}$ Department of Biochemistry and Molecular Pharmacology, ${ }^{3}$ Bioinformatics and Integrative Biology, ${ }^{4}$ UMMS \\ Proteomics and Mass Spectrometry Facility, University of Massachusetts Medical School, Worcester, Massachusetts 01655, USA \\ ${ }^{5}$ Albert Einstein College of Medicine, Bronx, New York 10461, USA
}

\begin{abstract}
Excision of introns from pre-mRNAs is mediated by the spliceosome, a multi-megadalton complex consisting of U1, U2, U4/U6, and U5 snRNPs plus scores of associated proteins. Spliceosome assembly and disassembly are highly dynamic processes involving multiple stable intermediates. In this study, we utilized a split TAP-tag approach for large-scale purification of an abundant endogenous U2·U5·U6 complex from Schizosaccharomyces pombe. RNAseq revealed this complex to largely contain excised introns, indicating that it is primarily ILS (intron lariat spliceosome) complexes. These endogenous ILS complexes are remarkably resistant to both high-salt and nuclease digestion. Mass spectrometry analysis identified 68, 45, and 43 proteins in low-salt-, high-salt-, and micrococcal nuclease-treated preps, respectively. The protein content of a $S$. pombe ILS complex strongly resembles that previously reported for human spliced product $(\mathrm{P})$ and Saccharomyces cerevisiae ILS complexes assembled on single pre-mRNAs in vitro. However, the ATP-dependent RNA helicase Brr2 was either substoichiometric in lowsalt preps or completely absent from high-salt and MNase preps. Because Brr2 facilitates spliceosome disassembly, its relative absence may explain why the ILS complex accumulates logarithmically growing cultures and the inability of $S$. pombe extracts to support in vitro splicing.
\end{abstract}

Keywords: intron lariat spliceosome; proteomic; RNAseq; spliceosome footprint; S. pombe

\section{INTRODUCTION}

Removal of introns from precursors to messenger RNAs (premRNAs) is an essential step in eukaryotic gene expression. Introns are excised by the spliceosome, a multi-megadalton machine composed of five uridine-rich small nuclear RNAs (U1, U2, U4, U5, and U6 snRNAs) and scores of polypeptides. Many proteins stably associate with the snRNAs to form small ribonucleoprotein particles (snRNPs), while many others function as transiently interacting "splicing factors." The snRNPs and splicing factors are thought to assemble de novo on each new intron via a highly dynamic process involving multiple stable intermediates. Recruitment of a U1 snRNP to the $5^{\prime}$ end of the intron ( $5^{\prime}$ splice site; $5^{\prime} \mathrm{SS}$ ) and U2 snRNP to the branch site (BS) near the $3^{\prime}$ end of the intron ( $3^{\prime}$ splice site; $3^{\prime} \mathrm{SS}$ ) results in pre-spliceosome (complex A) formation. Addition of the U5.U4/U6 tri-snRNP forms the pre-catalytic spliceosome (complex B), which is then converted to the activated spliceosome $\left(\mathrm{B}^{\mathrm{act}}\right)$ by a major structural rearrangement involving destabilization of U1 and U4 snRNPs and

\footnotetext{
${ }^{6}$ Corresponding author

E-mail melissa.moore@umassmed.edu

Article published online ahead of print. Article and publication date are at http://www.rnajournal.org/cgi/doi/10.1261/rna.040980.113.
}

addition of the multiprotein NineTeen Complex (NTC). Further structural rearrangements result in the catalytically active complexes $\left(\mathrm{B}^{*}, \mathrm{C} 1\right.$, and $\left.\mathrm{C} 2\right)$ in which the first $\left(5^{\prime} \mathrm{SS}\right.$ cleavage and lariat formation) and second (3'SS cleavage and exon ligation) chemical steps of splicing occur (Jurica and Moore 2003; Wahl et al. 2009; Hoskins and Moore 2012; Li et al. 2013). Spliced exon release from the spliced product complex (P) (Ilagan et al. 2013) results in formation of intron-lariat spliceosome complex (ILS) (Yoshimoto et al. 2009; Fourmann et al. 2013), containing the lariat intron, U2, U5, and U6 snRNAs and the NTC. ILS complex disassembly and subsequent reassembly of the U5.U4/U6 tri-snRNP completes the spliceosome cycle and readies the components for another round. Because each step in the spliceosome cycle involves the comings and goings of multiple components, each stable and isolatable complex has a signature RNA and protein composition (Jurica and Moore 2003; Wahl et al. 2009; Hoskins and Moore 2012).

(c) 2014 Chen et al. This article is distributed exclusively by the RNA Society for the first 12 months after the full-issue publication date (see http:// rnajournal.cshlp.org/site/misc/terms.xhtml). After 12 months, it is available under a Creative Commons License (Attribution-NonCommercial 3.0 Unported), as described at http://creativecommons.org/licenses/by-nc/3.0/. 
To date, most studies of spliceosome composition and structure have been performed on individual snRNPs or stable intermediate complexes assembled in vitro on a limited set of well-spliced premRNAs (Will and Luhrmann 2011). The latter complexes are usually obtained by artificially stalling spliceosome assembly or disassembly at a particular step (Jurica and Moore 2002; Jurica 2008). When endogenous spliceosomes have been isolated, they often contain protein components representative of multiple assembly states (Stevens 2000; Ohi et al. 2002; Chen et al. 2007). One notable exception is a stable endogenous complex containing U2, U5, and U6 snRNAs observed in logarithmically growing Schizosaccharomyces pombe (Huang et al. 2002). Previous purification of this complex (a.k.a., S. pombe CDC5 complex) via a TAP-tag on CDC5 revealed it to contain numerous orthologs of proteins associated with human C complex (McDonald et al. 1999; Ohi et al. 2002; Ren et al. 2011) and to structurally resemble human $\mathrm{C}$ complexes upon single particle reconstruction of electron microscope images (Ohi et al. 2007).

Here, we report large-scale isolation of these endogenous $S$. pombe U2-U5.U6 complexes using double-affinity purification via separate affinity tags affixed to two different proteins. Purifications were carried out under different stringencies to reveal both loosely and tightly bound factors. Comprehensive RNA and protein compositional analyses reveal this complex to consist largely of endogenous ILS complex. The absence of SF3A/B components coupled with the micrococcal nuclease cleavage pattern of $\mathrm{U} 2$ snRNA reveals new information about spliceosome conformational and compositional changes following spliced exon release. Finally, the relative absence of proteins required for spliceosome disassembly may explain why this complex accumulates in rapidly dividing S. pombe and why extracts from these cells fail to support in vitro splicing.

\section{RESULTS}

\section{Split TAP-tag purification of endogenous $S$. pombe U2·U5.U6 complexes}

S. pombe cell lysates contain significant amounts of a U2.U5.U6 snRNA complex indicative of post-activation spliceosomes (Huang et al. 2002; Ohi et al. 2002; Ren et al. 2011). To specifically purify this complex, we utilized a split TAP-tag approach, with protein A attached to U2 snRNP protein Lea1
(U2 $\mathrm{A}^{\prime}$ in human) and calmodulin binding peptide (CBP) attached to U5 snRNP protein Snu114 (U5 116K in human). An additional GFP tag on Cdc5 (an NTC component), Spp42 (U5 snRNP protein Prp8), or Brr2 (another U5 protein) allowed for real-time monitoring of later purification steps, as well as assessment of the extent to which the GFP-tagged species copurified with Leal and Snu114 (Fig. 1A). All three tags were introduced by homologous recombination into haploid cells, with tagged proteins replacing their untagged counterparts. Growth rates and cell morphologies of all triple-tagged strains were indistinguishable from the parental untagged strain (data not shown), indicating functionality of the fusion proteins.

To maximize yields, cells were grown in $5 \times$ YES media and harvested in late log phase $(\mathrm{OD} 600=\sim 23)$. Following cell lysis, immunoglobulin G (IgG)-sepharose and calmodulin affinity steps were carried out as described (Materials and Methods). Physiological (low salt; LS) complexes were obtained from $400 \mathrm{mM} \mathrm{KCl}$ cell lysate and purified in 150 $\mathrm{mM} \mathrm{NaCl}$. Increasing lysate $\mathrm{KCl}$ to $700 \mathrm{mM}$ significantly increased yields, but $1 \mathrm{M}$ total salt resulted in very low yields (Supplemental Fig. S1A). Salt-stable core (high salt; HS) complexes were thus obtained from $700 \mathrm{mM} \mathrm{KCl} \mathrm{ly-}$ sates and exposed to $700 \mathrm{mM} \mathrm{NaCl}$ during early purification stages to remove loosely bound factors. Treatment of these HS complexes with MNase (MN) during the IgG- 
sepharose step removed solvent-accessible RNA sequences. In all three preps (LS, HS, and MN), total protein and CDC5-GFP fluorescence exhibited identical calmodulin elution profiles (Fig. 1B; Supplemental Fig. S1B). Generally, $6 \mathrm{~L}$ of culture yielded $\sim 250 \mathrm{~g}$ packed cell pellet from which we were able to purify $\sim 2 \mathrm{mgs}$ of endogenous U2.U5.U6 snRNA complexes.

To assess complex integrity and hetereogeneity, HS complexes were analyzed by dynamic light scattering (DLS) and negative stain electron microscopy (EM). DLS revealed one major species with an estimated diameter of $34 \mathrm{~nm}$ and $\mathrm{MW}$ of $\sim 2.5 \mathrm{MDa}$ (Fig. 1C). Consistent with this, electron micrographs (Fig. 1D) revealed largely monodispersed ( $>95 \%$ monomer, $<5 \%$ dimer) 30 - to $35-\mathrm{nm}$ particles of uniform size and reproducible shape similar to human C complex (Jurica et al. 2004) and S. pombe CDC5 complex (Ohi et al. 2007). Negative stain EM images of LS and MN particles yielded similar results (Supplemental Fig. S1C).

\section{Protein composition of endogenous U2·U5·U6 complexes}

SDS-PAGE revealed nearly identical protein banding patterns for the LS, HS, and MN preps (Fig. 2A, left). Quantitative analysis by liquid chromatography-coupled tandem mass spectrometry (LC-MS/MS) revealed 29 abundant proteins common to all three preps (Fig. 2A, right; Table 1). Consistent with other analyses of in vitro-assembled spliceosomes (Schmidt et al. 2010; Agafonov et al. 2011; Ilagan et al. 2013), the most abundant species was Prp19, having a threeto fourfold higher stoichiometry than any other polypeptide. In isolation, Prp19 is a known tetramer (Ohi et al. 2005). All other abundant species were present at an approximately 1:1 stoichiometry, with the exception of translation elongation factor EF1A, which was significantly reduced in the $\mathrm{MN}$ prep. Multiple substoichiometric proteins were also present, with a total of 68,45 , and 43 species being consistently quantifiable in the LS, HS, and MN preps, respectively (Table 1).
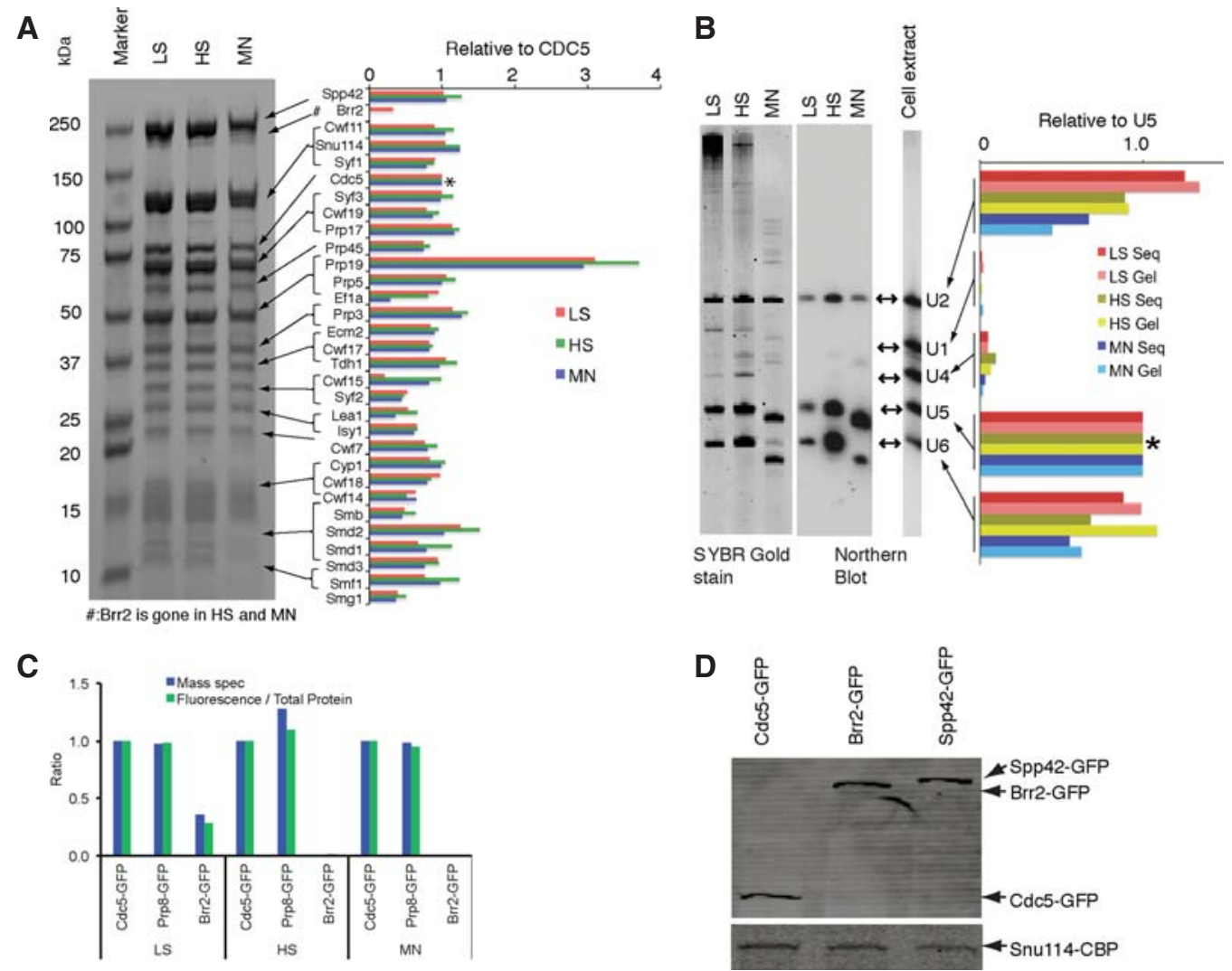

FIGURE 2. Protein and RNA compositions of purified U2·U5·U6 complexes. (A) Protein composition. Left: Coomassie blue-stained SDS-PAGE of total protein from LS, HS, and MN preps. Right: Abundances of major proteins relative to CDC5 $\left(^{*}\right)$ in each prep. Protein stoichiometries were estimated by quantitative mass spec (see Materials and Methods). (B) RNA composition. Left: SYBR Gold staining of LS, HS, and MN prep RNAs resolved by denaturing PAGE. Center: Northern blots using probes for U1, U2, U4, U5, and U6 snRNAs of same RNAs at left, plus RNA purified from total cell extract. Right: Relative snRNA stoichiometries to U5 $\left(^{*}\right)$ in LS, HS, and MN preps as determined by SYBR Gold staining (Gel) and RNAseq (Seq). (C) Endogenous S. pombe U2.U5.U6 complexes contain substoichiometric or undetectable amounts of Brr2 (related to $A$ and $C$ ). Bar graph of amounts of Spp42 (Prp8) and Brr2 relative to CDC5 in LS, HS, and MN preps. Fluorescence signals were compared by normalizing to total protein. $(D)$ Western blots showing expression levels of GFP-tagged proteins in cell extracts, with the expression levels of CBP-tagged on Snu114 in cell extracts as control. 
TABLE 1. Proteins detected in LS, HS, and MN preps

\begin{tabular}{|c|c|c|c|c|c|c|c|c|c|c|c|}
\hline \multicolumn{6}{|c|}{ Proteins } & \multicolumn{2}{|l|}{ LS } & \multicolumn{2}{|l|}{$\mathrm{HS}$} & \multicolumn{2}{|l|}{$\mathrm{MN}$} \\
\hline$\#$ & S. pombe & S. cerevisiae & Human & Accession number ${ }^{\mathrm{a}}$ & MW (kDa) & \# Peptides & $\mathrm{RS}^{\mathrm{b}}$ & \# Peptides & $\mathrm{RS}^{\mathrm{b}}$ & \# Peptides & $\mathrm{RS}^{\mathrm{b}}$ \\
\hline 1 & Prp19 & Prp19 & hPRP19 & SPAC29A4.08C & 54 & 23 & 2.95 & 19 & 2.99 & 20 & 2.94 \\
\hline 2 & Prp3 & Prp3 & hPRP3 & SPAC $3 A 12.11 \mathrm{C}$ & 44 & 17 & 1.07 & 18 & 1.23 & 16 & 1.28 \\
\hline 3 & Smd2 & Smd2 & Smd2 & SPAC2C $4.03 c$ & 13 & 7 & 1.03 & 6 & 1.10 & 6 & 1.03 \\
\hline 4 & Syf3 & Syf3 & hSYF3 & SPBC31F10.11c & 81 & 40 & 1.00 & 39 & 1.03 & 39 & 0.98 \\
\hline 5 & Prp5 & Prp46 & PRL1 & SPBP22H7.07 & 52 & 25 & 1.00 & 22 & 1.00 & 23 & 1.00 \\
\hline 6 & Cdc5 & Cef1 & Cdc5L & SPAC644.12 & 87 & 50 & 1.00 & 50 & 1.00 & 49 & 1.00 \\
\hline 7 & Cwf15 & Cwc15 & CCAP2 & SPBC337.06c & 30 & 11 & 0.99 & 9 & 1.00 & 12 & 0.97 \\
\hline 8 & Prp17 & Prp17 & hPRP17 & SPBC6B1.10 & 63 & 31 & 0.98 & 27 & 0.97 & 33 & 1.17 \\
\hline 9 & Snu114 & Snu114 & U5-116K & SPBC215.12 & 111 & 49 & 0.98 & 48 & 0.96 & 51 & 1.25 \\
\hline 10 & Spp42 & Prp8 & U5-220K & SPAC4F8.12C & 275 & 76 & 0.97 & 83 & 0.94 & 88 & 1.06 \\
\hline 11 & Ef1a & Tef1 & Ef1- $\alpha 1$ & SPCC794.09c & 50 & 10 & 0.95 & 8 & 0.93 & 8 & 0.29 \\
\hline 12 & Smd3 & Smd3 & Smd3 & SPBC19C2.14 & 11 & 8 & 0.94 & 6 & 0.92 & 6 & 0.76 \\
\hline 13 & Cwf18 & & CCDC12 & SPCP1E11.07C & 17 & 11 & 0.92 & 9 & 0.86 & 10 & 0.80 \\
\hline 14 & Tdh1 & Tdh1 & & SPBC32F12.11 & 36 & 15 & 0.23 & 17 & 0.86 & 18 & 0.77 \\
\hline 15 & Syf1 & Syf1 & hSYF1 & SPBC211.02c & 93 & 39 & 0.85 & 36 & 0.84 & 40 & 0.78 \\
\hline 16 & Cwf11 & & KIAA0560 & SPBC646.02 & 148 & 32 & 0.84 & 35 & 0.81 & 34 & 1.04 \\
\hline 17 & Ecm2 & Ecm2 & RBM22 & SPCC550.02c & 40 & 28 & 0.80 & 23 & 0.77 & 25 & 0.90 \\
\hline 18 & Cwf17 & & U5-40K & SPBC1289.11 & 37 & 21 & 0.77 & 18 & 0.77 & 19 & 0.82 \\
\hline 19 & Cwf19 & & CWF19L2 & SPAC30D11.09 & 74 & 45 & 0.76 & 46 & 0.76 & 44 & 0.87 \\
\hline 20 & Сур1 & & PPIL1 & SPAC57A10.03 & 17 & 9 & 0.74 & 7 & 0.75 & 8 & 0.99 \\
\hline 21 & Smf1 & Smf1 & Smf1 & SPBC3E7.14 & 9 & 7 & 0.73 & 6 & 0.72 & 5 & 0.97 \\
\hline 22 & Cwf7 & & Spf27 & SPBC28F2.04c & 21 & 16 & 0.71 & 17 & 0.71 & 16 & 0.80 \\
\hline 23 & Smd1 & Smd1 & Smd1 & SPAC27D7.07c & 13 & 7 & 0.71 & 6 & 0.68 & 5 & 0.79 \\
\hline 24 & Prp45 & Prp45 & SKIP & SPCC188.11 & 63 & 32 & 0.67 & 28 & 0.67 & 27 & 0.74 \\
\hline 25 & Isy1 & Isy1 & hISY1 & SPBC32F12.05C & 26 & 14 & 0.65 & 10 & 0.66 & 12 & 0.62 \\
\hline 26 & Cwf14 & Dub31 & G10 & SPBC24C6.11 & 17 & 8 & 0.63 & 6 & 0.53 & 7 & 0.64 \\
\hline 27 & Lea1 & Lea1 & $\cup 2 A^{\prime}$ & SPBC1861.08c & 27 & 13 & 0.58 & 10 & 0.53 & 10 & 0.36 \\
\hline 28 & Syf2 & Syf2 & Syf2 & SPBC3E7.13c & 28 & 15 & 0.49 & 14 & 0.51 & 11 & 0.44 \\
\hline 29 & Smb & Smb1 & Smb & SPAC26A3.08 & 15 & 9 & 0.43 & 8 & 0.42 & 7 & 0.44 \\
\hline 30 & Smg1 & Smg1 & Smg1 & SPBC4B4.05 & 9 & 6 & 0.36 & 4 & 0.23 & 3 & 0.37 \\
\hline 31 & Cwf16 & Yju2 & CCDC130 & SPBC18H10.10c & 34 & 9 & 0.13 & 8 & 0.20 & 9 & 0.21 \\
\hline 32 & Gpd3 & & & SPBC354.12 & 36 & 6 & 0.14 & 4 & 0.10 & 4 & 0.12 \\
\hline 33 & Ssa2 & Ssa1 & CCAP1 & SPCC1739.13 & 70 & 9 & 0.24 & 6 & 0.10 & 7 & 0.11 \\
\hline 34 & Pabp & Pab1 & Pabp1 & SPAC57A7.04C & 72 & 13 & 0.14 & 9 & 0.08 & 0 & \\
\hline 35 & Cps8 & Act1 & Actg1 & SPBC $32 \mathrm{H} 8.12 \mathrm{C}$ & 42 & 10 & 0.19 & 8 & 0.06 & 8 & 0.14 \\
\hline 36 & Bis1 & & & SPCC364.02C & 43 & 10 & 0.15 & 9 & 0.02 & 12 & 0.17 \\
\hline 37 & Rpl13 & Rpl13 & Rpl13 & SPAC664.05 & 24 & 6 & 0.40 & 1 & & 0 & \\
\hline 38 & Sde2 & & C1orf55 & SPAC31G5.18c & 29 & 4 & 0.39 & 0 & & 0 & \\
\hline 39 & Brr2 & Brr2 & U5-200K & SPAC9.03c & 249 & 4 & 0.36 & 0 & & 0 & \\
\hline 40 & Rps18-1 & Rps18a & Rps18 & SPBC16D10.11C & 17 & 2 & & 0 & & 0 & \\
\hline 41 & Rpl8-1 & Rpl2 & Rpl8 & SPAC1F7.13C & 27 & 6 & 0.34 & 1 & & 1 & \\
\hline 42 & Rps11-2 & Rps11a & Rps11 & SPAC144.11 & 18 & 3 & 0.27 & 0 & & 0 & \\
\hline 43 & Rpl4-1 & Rpl4 & Rpl4 & SPBP8B7.03C & 40 & 6 & 0.25 & 2 & & 4 & 0.09 \\
\hline 44 & Prp43 & Prp43 & hPrp43 & SPBC $16 \mathrm{H} 5.10 \mathrm{C}$ & 84 & 4 & 0.25 & 0 & & 0 & \\
\hline 45 & Rps1-2 & Rps1a & Rps1 & SPAC $22 \mathrm{H} 12.04 \mathrm{C}$ & 29 & 4 & 0.25 & 0 & & 0 & \\
\hline 46 & Ntr1 like & Ntr1 & Tfip11 & SPAC $1486.03 \mathrm{C}$ & 92 & 4 & 0.24 & 0 & & 0 & \\
\hline 47 & Orphan & & & SPAC17A2.08C & 31 & 4 & 0.18 & 0 & & 0 & \\
\hline 48 & Rpl25a & Rpl25a & Rpl25 & SPBC106.18 & 16 & 2 & & 0 & & 0 & \\
\hline 49 & Rpl12-1 & Rpl12a & Rpl12 & SPCC16C4.13c & 18 & 5 & 0.14 & 1 & & 2 & \\
\hline 50 & Rpl19-2 & Rpl19 & Rpl19 & SPCC1682.14 & 23 & 5 & 0.12 & 1 & & 2 & \\
\hline 51 & Sap145 & Cus1 & Sf3b145 & SPAC22F8.10c & 69 & 3 & 0.12 & 0 & & 0 & \\
\hline 52 & Мср60 & Hsp60 & Hspd1 & SPAC12G12.04 & 62 & 5 & 0.11 & 1 & & 0 & \\
\hline 53 & Rps2 & Rps2 & Rps2 & SPCC576.08c & 28 & 3 & 0.11 & 0 & & 1 & \\
\hline 54 & Rpl3 & Rpl3a & Rpl3 & SPAC17A5.03 & 44 & 2 & & 0 & & 1 & \\
\hline 55 & Rpl20 & Rpl20a & Rpl20 & SPAC26A3.04 & 21 & 2 & & 0 & & 1 & \\
\hline 56 & Rps7 & Rsp7 & Rps7 & SPAC18G6.14c & 22 & 6 & 0.10 & 2 & & 0 & \\
\hline 57 & prp22 & Prp22 & hPrp22 & SPAC10F6.02C & 131 & 4 & 0.10 & 0 & & 0 & \\
\hline 58 & Mug161 & Drn1 & Cwf19L2 & SPAC1F3.09 & 63 & 2 & & 0 & & 0 & \\
\hline
\end{tabular}


TABLE 1. Continued

\begin{tabular}{|c|c|c|c|c|c|c|c|c|c|c|c|}
\hline \multicolumn{6}{|c|}{ Proteins } & \multicolumn{2}{|l|}{ LS } & \multicolumn{2}{|l|}{$\mathrm{HS}$} & \multicolumn{2}{|l|}{$\mathrm{MN}$} \\
\hline$\#$ & S. pombe & S. cerevisiae & Human & Accession number ${ }^{\mathrm{a}}$ & MW (kDa) & \# Peptides & $\mathrm{RS}^{\mathrm{b}}$ & \# Peptides & $\mathrm{RS}^{\mathrm{b}}$ & \# Peptides & $\mathrm{RS}^{\mathrm{b}}$ \\
\hline 59 & Rpl23-1 & Rpl23a & Rpl23 & SPAC3G9.03 & 15 & 2 & & 0 & & 0 & \\
\hline 60 & Sme1 & Sme1 & Sme & SPBC11G11.06c & 10 & 5 & 0.08 & 1 & & 2 & \\
\hline 61 & Cip1 & Pin4 & & SPBC16A3.18 & 53 & 2 & & 0 & & 0 & \\
\hline 62 & Rps8-2 & Rps8b & Rps8 & SPAC521.05 & 23 & 2 & & 0 & & 0 & \\
\hline 63 & Sap155 & Hsh155 & Sf3b155 & SPAC27F1.09C & 135 & 2 & & 0 & & 0 & \\
\hline 64 & Sum3 & Ded1 & Ddx3 & SPCC1795.11 & 70 & 1 & & 0 & & 0 & \\
\hline 65 & Cip2 & & & SPAC12G12.03 & 62 & 2 & & 0 & & 0 & \\
\hline 66 & Rps15-2 & Rps15a & Rps15 & SPAC1071.07c & 18 & 2 & & 0 & & 0 & \\
\hline 67 & Rps3 & Rps3 & Rps3 & SPBC16G5.14c & 28 & 1 & & 0 & & 0 & \\
\hline 68 & Sap130 & Prp12 & Sf3b130 & SPAPJ698.03c & 135 & 2 & & 1 & & 0 & \\
\hline
\end{tabular}

${ }^{a}$ The accession numbers were taken from www.pombase.org.

${ }^{b}($ RS) Relative stoichiometry to CDC5 protein.

The additional polypeptides in the LS prep were predominantly ribosomal proteins.

With the exception of EF1A and Tdh1, all abundant polypeptides were proteins previously known to associate with spliceosomes. Most highly represented were the Sm snRNP core proteins, the NTC, the NTC-related complex, and U5 snRNP. Together, the latter three species comprise the 35S U5 complex (Makarov 2002; Makarova et al. 2004). The only abundant U2-specific protein was Lea1 (U2 A'), to which the protein A tag was attached. Notably, no substituents of SF3A or SF3B (U2 snRNP-associated complexes required for early spliceosome assembly steps) were detectable in either the HS or MN prep; this was consistent with the predominant purified species being a post-activation complex, as SF3A and B are destabilized coincident with spliceosome activation (Bessonov et al. 2008; Lardelli et al. 2010). Also notably absent from the HS prep were the second step factors Slu7, Prp22, and Prp18, all of which are abundant components of Saccharomyces cerevisiae $\mathrm{C}$ complex purified under LS-like conditions (Fabrizio et al. 2009). Slu7 was found in human P complex (Ilagan et al. 2013), and S. cerevisiae ILS complex (Fourmann et al. 2013) but was undetectable in our preparations (Fig. 5, below). The only known second step factor present in stoichiometric amounts in the HS and MN preps was Prp17, as has also been observed in human salt-stable $\mathrm{C}$ complex core preparations (Bessonov et al. 2008), human P complex (Ilagan et al. 2013), and S. cerevisiae ILS complex (Fourmann et al. 2013).

Surprisingly, the U5-specific protein Brr2 was threefold less abundant than other U5 proteins (e.g., Spp42, Snu114, and Cwf17) in the LS prep and undetectable in the HS and MN preps (Table 1; Fig. 2A). Consistent with this, Brr2GFP fluorescence was threefold reduced relative to either CDC5-GFP or Spp42-GFP in LS preps and was completely absent from HS preps (Fig. 2C). Western blotting revealed that this was not due to poor Brr2-GFP expression, as its levels in cell extracts were comparable to those of CDC5-GFP and Spp42-GFP (Fig. 2D). Thus, Brr2 is not stably associated with endogenous $S$. pombe U2·U5.U6 complexes. In contrast, Brr2 is an abundant component of both S. cerevisiae and human C complexes (Bessonov et al. 2008; Fabrizio et al. 2009) as well as human P complex (Ilagan et al. 2013) and S. cerevisiae ILS complex (Fourmann et al. 2013). Thus, with regard to their protein content, endogenous $S$. pombe U2.U5.U6 complexes are similar, but not identical, to human $\mathrm{C}$ and $\mathrm{P}$ complexes and S. cerevisiae C and ILS complexes.

\section{RNA composition of purified complexes}

RNAs in the LS, HS, and MN preps were analyzed both by denaturing PAGE and high-throughput sequencing (RNAseq) (see Materials and Methods). SYBR Gold staining of gels revealed three major 100- to 200-nt bands in the LS and HS preps (Fig. 2B, left). Northern blotting confirmed that these were U2, U5, and U6 snRNAs (Fig. 2B, center). SYBR Gold staining and RNAseq revealed three snRNAs to be present at comparable ratios (Fig. 2B, right). The next most abundant small RNA species were $\mathrm{U} 4$ and $\mathrm{U} 1$, with relative stoichiometries of 0.05 and 0.01 , respectively. Other small RNAs (e.g., snoRNAs and tRNAs) collectively constituted $<0.5 \%$ of the total. Thus, the bulk of our purified complexes constituted post-activation spliceosomes (i.e., subsequent to U1 and U4 departure).

In the MN sample, both U5 and U6 snRNAs were quantitatively converted to faster migrating species, but their relative stoichiometries remained largely unchanged. RNAseq revealed that MNase removed $4 \mathrm{nt}$ from the $5^{\prime}$ end of U5 and $5 \mathrm{nt}$ from the $3^{\prime}$ end of U6 (Fig. 3A,B). Although migration of $\mathrm{U} 2$ was apparently unaffected by MNase treatment, its relative stoichiometry was reduced by nearly half. Analysis of the $5^{\prime}$ and $3^{\prime}$ termini of U2-mapping RNAseq tags in the MN library indicated two major cleavage sites: (1) within the GUAGUA branch recognition sequence; and (2) at the base of the penultimate stem-loop (Fig. 3B). The region between these two cleavage sites (within which our Northern probe 

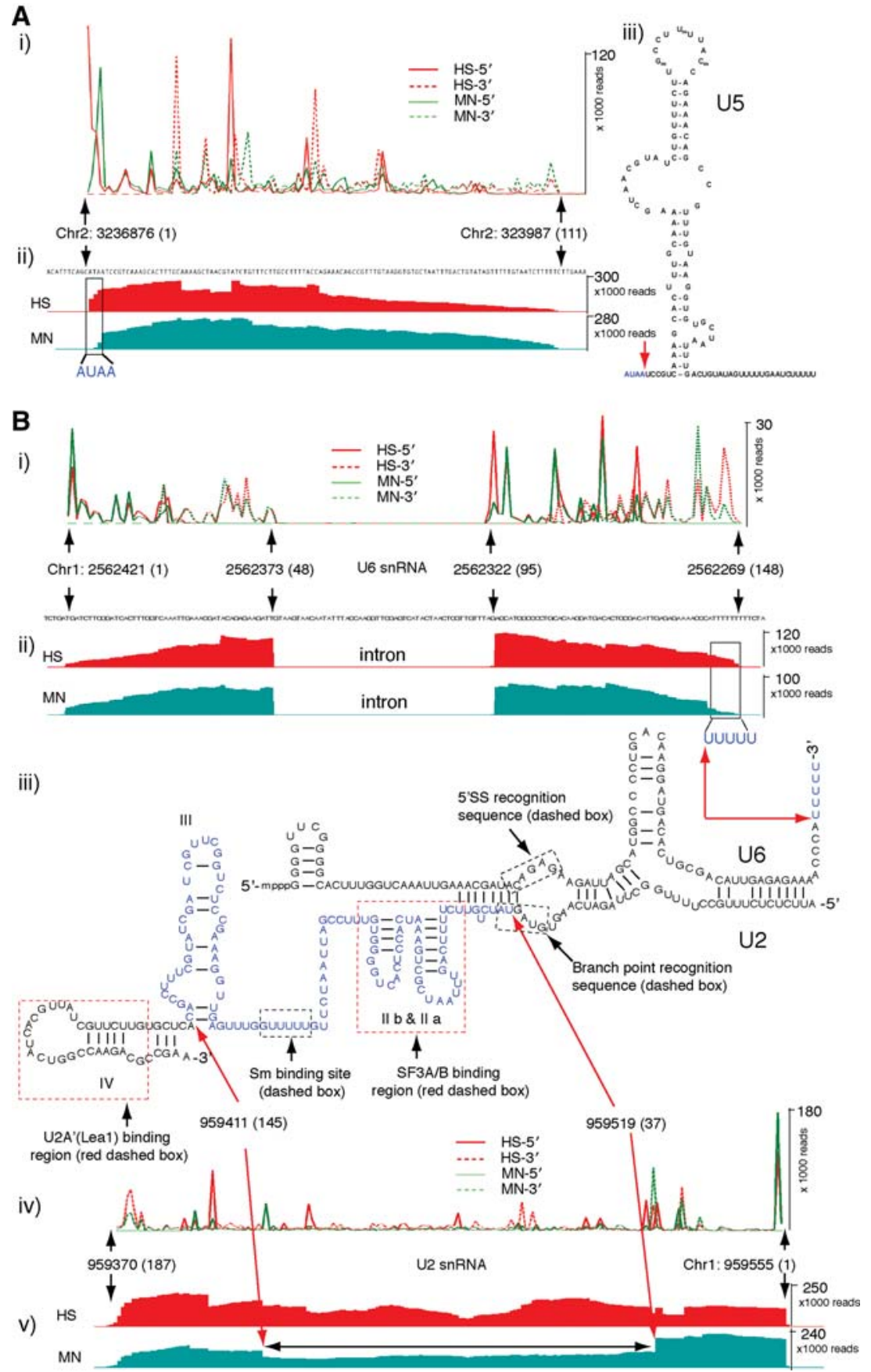

FIGURE 3. MNase cleavage site in U5, U6/U2 snRNAs. (A) MNase cleavage site in U5 snRNA. (i) Distribution of $5^{\prime}$ and $3^{\prime}$ tag ends in HS and MN libraries on U5 snRNA. (ii) UCSC screen shot showing full length $S$. pombe U5 snRNA. (iii) U5 secondary structure and MNase cleavage site (red arrow). (B) MNase cleavage sites in U6/U2 snRNAs. (i) Distribution of $5^{\prime}$ and $3^{\prime}$ tag ends in HS and MN libraries on U6 snRNA. (ii) UCSC screen shot showing full length S. pombe U6 snRNA. (iii) U6 secondary structure $\left(5^{\prime}-3^{\prime}\right)$ and MNase cleavage site (red arrow) and U2 secondary structure $\left(3^{\prime}-5^{\prime}\right)$ and MNase cleavage site (red arrow). (iv) UCSC screen shot showing full length $S$. pombe U2 snRNA. (v) Distribution of $3^{\prime}$ and $5^{\prime}$ tag ends in HS and MN libraries on U2 snRNA.

was located) was twofold underrepresented in the RNAseq data compared to the $5^{\prime}$ and $3^{\prime}$ ends. Additional Northern blotting with probes complementary to other regions in U2 confirmed the existence of numerous fragments in the $\mathrm{MN}$ sample (Supplemental Fig. S2). Thus, our purified complexes either contain two distinct U2 conformers (one fully protected from nuclease digestion and another in which the region between the branch recognition sequence and the penultimate stem-loop is nucleaseaccessible), or this region of U2 snRNA is kinetically less accessible to MNase digestion than are the $5^{\prime}$ and $3^{\prime}$ ends of U5 and U6 snRNA, respectively.

\section{Genome-wide analysis of RNAseq reads}

In addition to U2, U5, and U6 snRNAs, heterogeneous higher molecular weight species were clearly present in all three samples (Fig. 2B, left). To identify these, we performed genome-wide analysis of our RNAseq tags using a stringent mapping algorithm (see Materials and Methods; see Supplemental Table S1A for data statistics). Of reads mapping to the S. pombe genome, $98 \%, 98 \%$, and $99 \%$ (LS, HS, and MN libraries, respectively) mapped both within and sense to annotated genes. Further, of the nongenome mapping reads, 94\%-99\% mapped sense to exon-exon junctions in the predicted transcriptome. Thus, almost all of our mappable reads corresponded to the annotated $S$. pombe transcriptome (Rhind et al. 2011).

Known S. pombe genes can be divided into seven broad classes: CDS, rRNAs, snRNAs, snoRNAs, tRNAs, long terminal repeat (LTR)-containing transcripts, and other miscellaneous RNAs. The vast majority ( $\geq 99.5 \%)$ of tags mapping to known genes (including introns) mapped to the snRNA, rRNA, or CDS class, but the relative abundances among these classes varied among the three preps (Fig. $4 \mathrm{~A})$. Consistent with higher ribosomal protein abundance in the LS prep (Table 1), $40 \%$ of LS tags were from rRNA, compared to only $10 \%$ and $20 \%$ of HS and MN tags. Fewer tags in the MN library mapped to the CDS class (6\%) than in the LS (17\%) and HS (14\%) libraries. This was also expected, as MNase should eliminate any sequences not directly protected by the spliceosome (see below).

There was excellent correlation between tag abundances mapping to individual CDSs across all three preps $(r>0.8)$, 


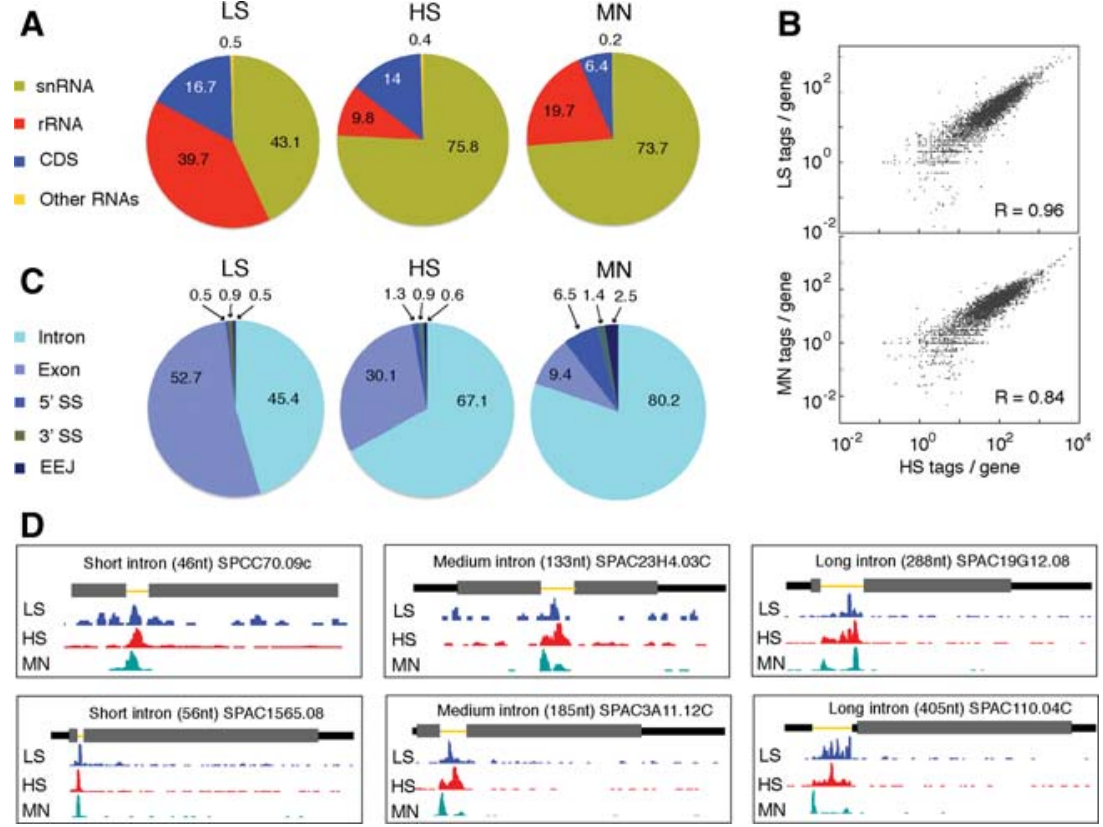

FIGURE 4. RNAseq data for LS, HS, and MN endogenous U2.U5.U6 complex preps. (A) Pie charts showing class distributions of transcript mapping reads for LS (left), HS (middle), and MN (right) libraries. The "Other RNAs" class includes snoRNAs, tRNAs, misc-RNAs, and long terminal repeats (LTRs). (B) $\log _{2}$ plots of tag abundance per CDS gene reveal excellent correlations between LS, MN, and HS libraries. $(C)$ Pie charts showing distributions of intron, exon, 5'SS, 3'SS, and exon-exon junction mapping reads among the LS (left), HS (middle), and MN (right) libraries. (D) Two examples each of genes with a short (left: 46 and $56 \mathrm{nt}$ ), medium length (middle: 133 and $185 \mathrm{nt}$ ), or long (right: 288 and $405 \mathrm{nt}$ ) intron showing coverage of LS, HS, and $\mathrm{MN}$ tags along the gene. Thick gray rectangles: coding regions; medium black lines: UTRs; thin yellow lines: introns. Consistent with the pie chart in $C$, the LS library contains the most exonmapping reads, whereas $\mathrm{MN}$ reads are almost exclusively confined to introns. Note the single $\mathrm{MN}$ peak on short introns and double MN peaks on medium length and long introns.

indicating the high quality of our data (Fig. 4B). Out of the 2345 annotated intron-containing CDS genes in S. pombe, only 73 had no uniquely mapping reads in the MN data set and $<5$ reads in the HS data set. Close reexamination of the S. pombe transcriptome RNAseq data (Rhind et al. 2011) revealed that 70 of these are misannotated introns, while the remaining three are poorly expressed in late log phase (W Chen, H Shulha, N Rhind, Z Weng, M Moore, in prep.). Thus, our data cover $99.9 \%$ of intron-containing CDS genes.

\section{Endogenous U2·U5·U6 complexes contain predominantly excised introns}

Among CDS mapping tags, the fraction mapping to introns and exons of single-intron genes varied among the three preps in expected ways (Fig. 4C; Supplemental Table S1C). The vast majority of $\mathrm{MN}$ tags were intronic, consistent with the idea that only regions protected by spliceosomes survive MNase digestion. In the LS and HS preps, both of which initially contained intact RNAs, the percentage of total tags mapping to exons was higher in the LS prep than in the HS prep. This suggests that exonic regions were preferentially dissociated upon high-salt treatment. All of these data features were readily apparent on individual genes (Fig. 4D).

To more rigorously examine the possibility that exonic regions were less stably bound to our purified complexes than intronic regions, we calculated intron and exon tag densities for the most abundant single-intron CDS genes represented in the LS and HS preps (Table 2). In both preps, $5^{\prime}$ and $3^{\prime}$ exon tag densities were highly similar, indicating no preferential dissociation of the $5^{\prime}$ exon as might be expected for splicing intermediate-containing complexes. Further, the higher intron:exon ratio in the HS prep (12.714.4) than the LS prep (6.5-7.4) indicates that exonic sequences were prone to dissociation under high-salt conditions. Thus, the predominant CDS RNA species (93\% for the HS prep) consisted of introns no longer associated with exons. This indicates that endogenous $S$. pombe U2.U5.U6 snRNA complexes are predominantly ILS complexes.

\section{DISCUSSION}

In this paper, we describe large-scale purification and comprehensive proteomics and ribonomics characterization of an abundant endogenous splicing complex containing U2, U5, and U6 snRNAs from S. pombe (Fig. 1A). RNAseq revealed that these endogenous complexes contain predominantly spliced intron products representing 99.9\% of intron-containing CDS genes. Consistent with this, the set of proteins stably associated with this endogenous U2.U5.U6 complex strongly resembles the proteins associated with intron lariat spliceosomes assembled in vitro on a single intron from S. cerevisiae (Fourmann et al. 2013). Thus, spliceosome disassembly from intron lariats is likely rate-limiting for pre-mRNA splicing during logarithmic

TABLE 2. Intron/exon tag densities and 5'SS, $3^{\prime}$ SS numbers

\begin{tabular}{lcc}
\hline Items & LS & HS \\
\hline Average intron tag density/gene $^{\mathrm{a}}$ & 0.390 & 0.663 \\
Average 5' exon tag density/gene $^{\mathrm{a}}$ & 0.053 & 0.052 \\
Average 3' exon tag density/gene $^{\mathrm{a}}$ & 0.060 & 0.046 \\
Intron tag density:5' exon tag density $^{\prime}$ & 7.4 & 12.7 \\
Intron tag density:3' exon tag density & 6.5 & 14.4 \\
ILS complex/all purified complexes (\%) & 88 & 93
\end{tabular}

Data from the top $10 \%$ of single intron genes with signal.

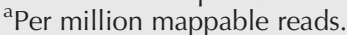


growth in S. pombe cells. A potential explanation for slow ILS complex disassembly is the relative absence of the ATPase Brr2, which is responsible for facilitating structural transitions involving $\mathrm{U} 2$ and U6 snRNAs.

\section{Protein compositional similarities and differences between C, P, and ILS complexes}

In comparison to the stable complexes observable during spliceosome assembly and activation, the complexes involved in spliceosome disassembly have been much less studied. One paper described isolation of two post-splicing complexes, Intron Large (IL) and Intron Small (IS), from in vitro splicing reactions in HeLa nuclear extract containing a chicken c-crystallin splicing substrate with three MS2 binding sites in the intron (Yoshimoto et al. 2009). Purified IL complex contained U2, U5, and U6 snRNAs and a number of bound proteins, whereas IS complex consisted largely of the naked intron. More recently, two other studies also employing the MS2 purification approach from in vitro splicing reactions reported much more comprehensive proteomics analyses of two late-stage splicing complexes: (1) HeLa P complex stalled on a splicing substrate derived from AdML pre-mRNA containing a very short (13-nt) $3^{\prime}$ exon that does not allow for efficient spliced exon release (Ilagan et al. 2013); and (2) S. cerevisiae ILS complex assembled on a splicing substrate derived from the Actin7 (Act7) pre-mRNA (Fourmann et al. 2013).

As expected, the protein composition of endogenous $S$. pombe ILS complexes closely resembles that of in vitro-assembled S. cerevisiae ILS complex (Fig. 5). Proteins shared between human P, S. cerevisiae ILS, and endogenous S. pombe ILS complexes include (with notable exceptions as discussed below) most U5, NTC, and NTC-related proteins. Taking into account the expected twofold and three- to fourfold stoichiometries of the Sm proteins and Prp19, respectively, and the snRNAs and protected intronic regions, the calculated MW of S. pombe ILS complexes is $2.1 \mathrm{MDa}(\mathrm{MN})$ to 3.5 $\mathrm{MDa}$ (LS). This is very similar to human C complex (estimated MW 2.6 MDa), consistent with previous EM reconstructions showing strong structural similarities between these two complexes (Jurica et al. 2004; Ohi et al. 2007).

Nonetheless, numerous proteins stably associated with human C complex are missing from all three post-splicing complexes characterized to date. Several are displaced upon spliced exon dissociation by Prp22 (Fourmann et al. 2013). These include the second step factors Slu7 and Prp18 (Zhang and Schwer 1997), the RES complex (Lst3, Bud13, Pml1) that functions in nuclear retention of spliceosomes (Dziembowski et al. 2004), and NTC components Cwc21 and Cwc22. Cwc21 interacts directly with Prp8 and influences the fidelity of splicing (Grainger et al. 2009). Cwc22 was recently shown to serve as the binding platform for exon junction complex (EJC) assembly on the spliced exons (Barbosa et al. 2012; Steckelberg et al. 2012). As expected for complexes predominated by lariat introns, we detected no EJC proteins in any of our endogenous ILS complex preparations.

\section{U2 snRNP proteins and U2 snRNA conformation}

In comparison to human P complex and S. cerevisiae ILS complex, a number of proteins are significantly underrepresented in or completely absent from $S$. pombe ILS complexes. Of particular note are all specific components of 17S U2 snRNP (Brosi et al. 1993a; Krämer et al. 1999) except for U2A' (Lea1), to which one of our affinity tags was attached. One missing protein is $\mathrm{U}^{2} \mathrm{~B}^{\prime \prime}$ (Msl1), an RNA recognition motif (RRM)-containing protein that binds the $3^{\prime}$-most structural element in U2 snRNA (stem-loop IV) as a heterodimer with U2A' (Scherly et al. 1990; Williams and Hall 2011). The complex of U2 snRNA, the Sm proteins, and the U2A': U2B" heterodimer comprise 12S U2 snRNP (Boelens et al. 1991). Although Msl1 is essential for vegetative growth in $S$. pombe (Kim et al. 2010), it is inessential in S. cerevisiae (Tang et al. 1996). Together with Leal, Msl1 has been implicated in pre-spliceosome formation and exhibits synthetic lethality with Mud2, a splicing factor involved in initial recruitment of U2 snRNP to the branch site (Abovich et al. 1994; Tang et al. 1996; Caspary 1998). Taken together, these data suggest that Msl1 functions primarily in early spliceosome assembly stages but is not required for overall spliceosome integrity. Although we observed no growth defects in our tagged $S$. pombe strains compared to the parental strain, it is possible that the presence of the protein A tag on Leal destabilized Msl1 association with U2 snRNA.

The remainder of $17 \mathrm{~S}$ U2 snRNP is comprised of the nine SF3A and B proteins (SF3A: SF3a60, SF3a66, SF3a120; SF3B: SF3b14b, SF3b14a, SF3b49, SF3b130, SF3b145, and SF3b155) (Behrens et al. 1993; Hodges and Beggs 1994; Bessonov et al. 2008). During U2 snRNP assembly in vitro, SF3B proteins bind first and then recruit the SF3A proteins (Behrens et al. 1993; Brosi et al. 1993a; Krämer et al. 1999). SF3B components bind U2 snRNA stem-loop IIa, whereas SF3A complex binds stem-loops IIa and IIb (Yan and Ares 1996; Lin and Xu 2012). SF3A and B also protect the region around the GUAGUA branch recognition sequence from chemical modification (Behrens et al. 1993; Yan and Ares 1996).

Both SF3A and SF3B are required for early spliceosome assembly (Brosi et al. 1993a,b). At that stage, SF3B components make extensive interactions with the pre-mRNA to either side of the branch site and are important for U2 snRNP recruitment and retention (Brosi et al. 1993a; Gozani et al. 1996). Three studies had suggested that SF3B's interaction with the rest of the spliceosome is destabilized upon catalytic activation of the human and S. cerevisiae spliceosomes (Bessonov et al. 2008, 2010; Lardelli et al. 2010). More recently, however, Coltri et al. (2011) identified SF3B proteins in human $\mathrm{C}$ complex; they proposed that SF3A and SF3B release their hold on U2 snRNA during spliceosome activation but maintain their grip on the intron, where they help to hold the 
Human P complex (a)

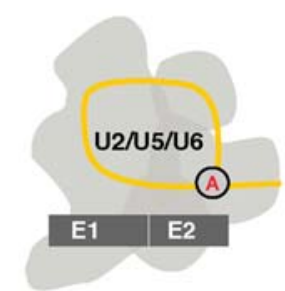

AdML intron with Exons

\begin{tabular}{|c|c|c|}
\hline U2 RNA & U6 RNA & U5 RNA \\
\hline $\begin{array}{l}\mathrm{Sm} \\
\mathrm{A}^{\prime} \\
\mathrm{B}^{\prime \prime}\end{array}$ & $\begin{array}{c}\text { KIAA1064 } \\
\text { srm300 }\end{array}$ & $\begin{array}{c}\text { Sm } \\
\text { hSnu114 } \\
\text { hBrr2 }\end{array}$ \\
\hline $\begin{array}{l}\text { St3b155 } \\
\text { St3b145 }\end{array}$ & $\begin{array}{l}\text { Prp19 } \\
\text { Cdc5 }\end{array}$ & $\begin{array}{c}\text { hPrp8 } \\
40 \mathrm{~K}\end{array}$ \\
\hline St3b130 & $\begin{array}{l}\text { Syf1 } \\
\text { Syi2 }\end{array}$ & Prp45 \\
\hline S13b49 & Isyi & Prp46 \\
\hline St3b14b & Snt309 & Cwc2 \\
\hline St3b10 & Cwf15 & Rbm22 \\
\hline Si3b14a & Clif1 & Ibp160 \\
\hline Prp21 & Ctnnbl1 & Bud31 \\
\hline Prp11 & $\begin{array}{l}\text { NpwDp } \\
\text { Ssa4 }\end{array}$ & Cyp1 \\
\hline Prp9 & Npw38 & Сурз3 \\
\hline Prp2 & $\begin{array}{l}\text { Prp43 } \\
\text { Ntr1 }\end{array}$ & \\
\hline & Prp38 & \\
\hline Cdc16 & Cactin & $\operatorname{LSm} 3$ \\
\hline Cwc27 & Ddx41 & LSm 4 \\
\hline $\begin{array}{l}\text { ISAPD } \\
\text { Cedc1? }\end{array}$ & Dgcr14 & Eif4a3 \\
\hline Cyp60 & Kiaa0073 & Pnn \\
\hline Prcc & Ppil3 & \\
\hline hPrp17 & Ppig & \\
\hline Prp22 & $\begin{array}{l}\text { C1orf55 } \\
\text { C9orf78 }\end{array}$ & \\
\hline hSlu7 & $\begin{array}{c}\text { Otag12 } \\
\text { Xap55 }\end{array}$ & \\
\hline & C10ort 4 & \\
\hline $\begin{array}{l}\text { Bud133 } \\
\text { Snip1 }\end{array}$ & Cxort56 & \\
\hline Cgi79 & $\begin{array}{l}\text { Leng1 } \\
\text { Srm300 }\end{array}$ & \\
\hline
\end{tabular}

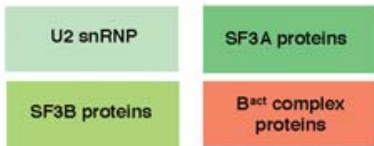

S. cerevisiae ILS complex ${ }^{(\mathrm{b})}$

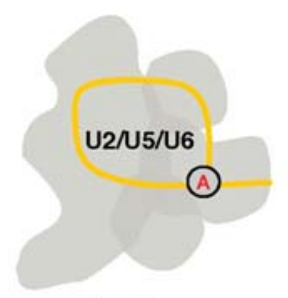

Act7 intron
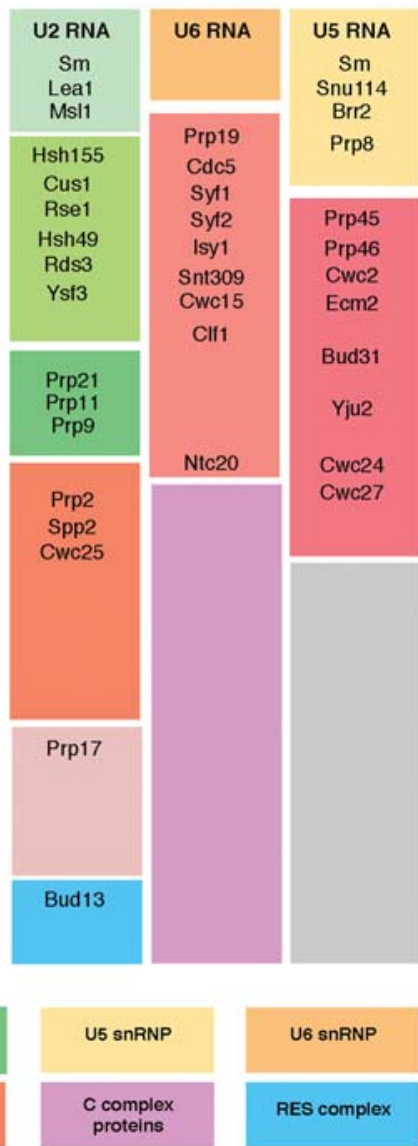

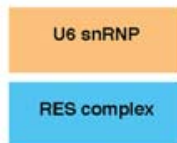

\section{Endogenous S. pombe ILS complex}

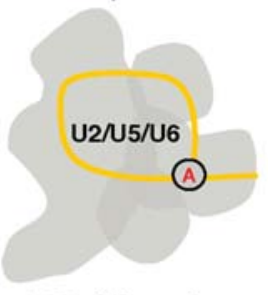

$>\mathbf{2 4 5 0}$ different introns
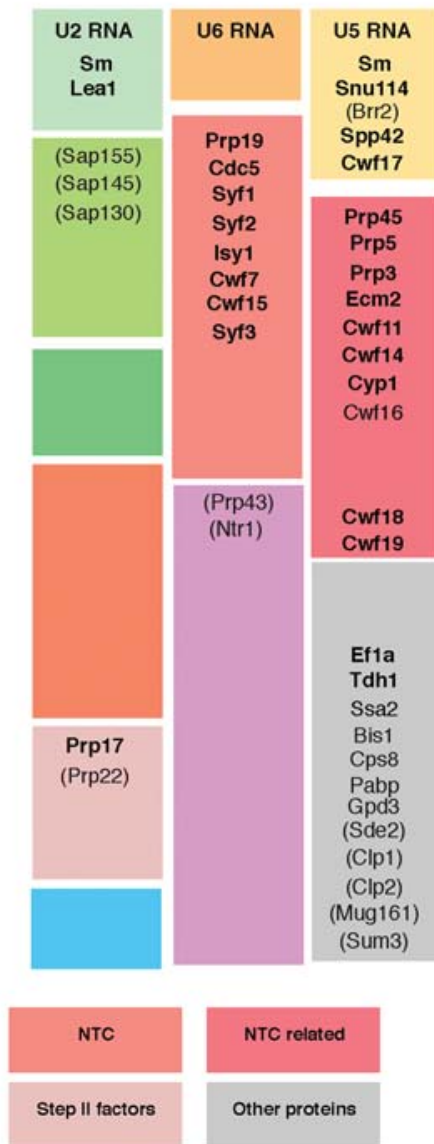

FIGURE 5. Proteins and RNAs composition of endogenous S. pombe ILS complex, S. cerevisiae ILS complex, and human P complex. Protein and snRNA compositions of human P complex ${ }^{\text {(a) }}$ (left; containing AdML spliced intron without releasing exons) (Ilagan et al. 2013), S. cerevisiae ILS complex $^{(b)}$ (middle; only containing single Act7 spliced inton) (Fourmann et al. 2013), and endogenous S. pombe U2.U5.U6 complexes (right; containing more than 2450 spliced introns). Proteins and snRNAs are grouped and color-coded according to complex association or function as indicated at the bottom. More abundant proteins are indicated in bold text; empty colored rectangles indicate the absence of proteins in that structural or functional category.

splicing intermediates in place. Consistent with this, SF3b145 and SF3b130 were recently detected in human $\mathrm{P}$ complex (Ilagan et al. 2013), and most of the SF3A/B proteins were identified in S. cerevisiae ILS complex (Fourmann et al. 2013).

Our data indicate that SF3A components are completely absent from endogenous $S$. pombe ILS complexes and that the SF3B proteins are only loosely bound-they were substoichiometric in LS complexes and completely absent from HS and MN complexes (Fig. 2B; Table 1). Consistent with this, our RNAseq results revealed two major MNase cleavage sites $(\downarrow)$ in $\mathrm{U} 2$ snRNA: one within the GUAG ${ }^{\downarrow} \mathrm{UA}$ branch recognition sequence and another at the $5^{\prime}$ end of stem-loop IV (Fig. 3B). Protection and retention of stem-loop IV is expected because this is the binding site of Leal (see above). Unexpected from previous data, however, is nuclease accessibility of the GUAGUA branch recognition sequence. A recent detailed study of snRNA nucleotide accessibility to chemical modification revealed only minimal modification of the GUAGUA sequence in pre- and post-activation spliceosomes (human B, B ${ }^{\text {act }}$, and C complex) (Anokhina et al. 2013) 
compared to downstream nucleotides (i.e., $3^{\prime}$ from the GUAGUA region). Our data thus suggest that after spliced exon release, the GUAGUA region becomes more solvent accessible, perhaps due to $\mathrm{SF} 3$ protein release.

\section{Spliceosome disassembly: a slow step in the S. pombe splicing cycle?}

Despite sustained efforts by several laboratories, no conditions have yet been found that allow complete spliceosome assembly and catalysis in S. pombe extracts. Whereas S. cerevisiae and human extracts contain significant amounts of U4/5/6 tri-snRNP ready to engage in new spliceosome assembly, crude $S$. pombe lysates are predominated by ILS complex (Huang et al. 2002). Therefore, spliceosome disassembly seems to be a slow step in the $S$. pombe splicing cycle. ILS complex disassembly requires the abundant DEAH ATPase, Prp43. In S. cerevisiae, Prp43 is recruited to post-second step spliceosomes by the NTC-related proteins Ntr1 and Ntr2 (Boon et al. 2006; Tanaka et al. 2007; Tsai et al. 2007). Ntr1 bridges Prp43 to Ntr2, which, in turn, interacts with the U5 snRNP protein and DEIH box ATPase Brr2 (Chen et al. 2013). Although S. pombe contains no clear Ntr2 homo$\log$, it is of note that Ntr1, Prp43, and Brr2 were all significantly substoichiometric in our purified complexes (Table 1).

During spliceosome acitivation, Brr2 functions to unwind the U4/U6 helices to enable release of U4 snRNA and formation of the catalytic core in which U6 is extensively basepaired with U2 (Laggerbauer et al. 1998). Brr2's ATPase activity is also required for spliceosome disassembly (Small et al. 2006; Hahn and Beggs 2010), and its ATPase activity in vitro is stimulated by hybridized U2 and U6 snRNAs (Xu et al. 1996). Thus, Brr2 likely functions to disrupt base-pairing interactions between $\mathrm{U} 2$ and U6 at this stage (Small et al. 2006). Because of its stable association with U5 snRNP as well as all major spliceosomal complexes in the human and S. cerevisiae systems, Brr2 was not previously thought to be a dynamically interacting splicing factor (Hahn and Beggs 2010). It was, therefore, surprising to us that Brr2 was significantly substoichiometric in (LS preps) or completely absent from (HS and MN preps) our purified endogenous $S$. pombe U2.U5.U6 complexes. Perhaps this unstable interaction of Brr2 with U2.U5.U6 complexes explains both ILS accumulation in logarithmically growing yeast and the inability of $S$. pombe extracts to support splicing in vitro (Huang et al. 2002).

\section{MATERIALS AND METHODS}

\section{S. pombe strain construction}

All strains derived from yFS 104 (ura4-D18 leu1-32 h+) and yFS 105 (ura4-D18 leu1-32 h-). The lea1 and snu114 chromosomal loci fused at their $\mathrm{C}$ termini either to a TEV cleavage site followed by protein $\mathrm{A}$ or to the calmodulin binding peptide were constructed by PCR-based gene targeting (Bahler et al. 1998) using plasmid
pFA6a-CTAP-MX6 (Tasto et al. 2001) as a PCR template. $c d c 5$, spp42 (prp8), and brr2 chromosomal loci were individually $3^{\prime}$ end GFP-tagged by PCR-based gene targeting using pFA6a-GFP (F64L, S65T)-kanMX6 (Bahler et al. 1998) as a PCR template. Strain MJM01 (Cdc5-GFP, Lea1-protein A, Snu114-CBP, ura4D18 leu1-32 h-) was generated by mating of appropriate parent strains, followed by sporulation and PCR validation of haploid derivatives. Strains MJM02 and MJM03 encoded Spp42-GFP and Brr2-GFP, respectively.

\section{Complex purification}

Purification of endogenous U2·U5.U6 complexes was carried out as previously described for TAP-tagged complexes (Puig et al. 2001) with the following modifications. For LS preps, cells from high-density cultures ( $5 \times$ YES; OD600 $=23-25)$ were washed in Buffer A (10 mM K-HEPES, pH 7.9, $40 \mathrm{mM} \mathrm{KCl,} 1.5 \mathrm{mM} \mathrm{MgCl}_{2}, 0.5 \mathrm{mM}$ DTT, $0.5 \mathrm{mM}$ PMSF, $2.0 \mathrm{mM}$ benzamidine), repelleted, frozen as noodles in liquid nitrogen, and pulverized to a powder in a ball mill (PM 100, Retsch). Frozen cell powder was resuspended in Buffer B (Buffer A with $400 \mathrm{mM} \mathrm{KCl}$ ) and the supernatant used for TAP purification in $150 \mathrm{mM} \mathrm{NaCl}$ as previously reported (Puig et al. 2001). Complexes were recovered from calmodulin resin by applying elution buffer containing 6 mM EGTA and collecting eight $400-\mu$ fractions. HS preps were identical except that frozen cell powder was resuspended in Buffer C (Buffer A with $400 \mathrm{mM} \mathrm{KCl}$ and $300 \mathrm{mM} \mathrm{NaCl}$ ), and the protein A binding and washing buffers contained $700 \mathrm{mM} \mathrm{NaCl}$. MN preps were the same as HS preps except complexes bound to IgG beads were treated with MNase prior to TEV cleavage. For all preps, elution fractions were assessed by GFP fluorescence and Bradford assays. Detailed purification protocols, dynamic light scattering, and negative stain electron microscopy are described in Supplemental Materials and Methods.

\section{Electron microscopy}

For EM, purified complex $(200 \mu \mathrm{g} / \mathrm{mL})$ was applied to glow-discharged, carbon-coated grids and negatively stained with $2 \%$ uranyl acetate. Micrographs $(66,000 \times$ magnification) were taken on a Philips CM12 microscope operating at $120 \mathrm{kV}$.

\section{Mass spectrometry}

Fifty micrograms total protein from each prep were digested with trypsin (Promega), and S. cerevisiae alcohol dehydrogenase (ADH) tryptic digest (P00330; Waters Inc.) was added to the digest as an internal standard (Silva et al. 2006). Each sample had $500 \mathrm{ng}$ of tryptic peptides injected in triplicate, and nanoflow separation was performed on a nanoACQUITY Ultra Performance Liquid Chromatography (UPLC) system (Waters) equipped with a 75$\mu \mathrm{m} \times 150-\mathrm{mm}$ analytical column packed with $1.7-\mu \mathrm{m}$ bridged-ethyl hybrid $(\mathrm{BEH}) \mathrm{C}_{18}$, by application of a linear 60 -min gradient from $3 \%$ to $90 \%$ acetonitrile (ACN) in $0.1 \%$ formic acid. A lock mass solution of $200 \mathrm{fmol} / \mu \mathrm{L}$ Glu-fibrinopeptide was delivered via the auxiliary solvent manager at $500 \mathrm{~nL} / \mathrm{min}$ into the reference sprayer of the NanoLockSpray source. Analysis of nano-UPLC elutes were performed on a Q-Tof Premier mass spectrometer (Waters) operated in the $\mathrm{V}$-mode, and alternating scans were used to detect precursor 
ions and then fragment ions. The masses of the precursor ions were detected with a low collision energy (CE) of $5 \mathrm{eV}$, which was followed by a scan where the $\mathrm{CE}$ was ramped from 15 to $40 \mathrm{eV}\left(\mathrm{MS}^{\mathrm{E}}\right.$ scan). MS data were analyzed using ProteinLynxGlobalServer (PLGS) Identity ${ }^{\mathrm{E}}$ Version 2.4 software (Waters) against the protein database Sanger $S$. pombe (www.sanger.ac.uk) which had been combined with an equalsized database consisting of the randomized sequences for the estimation of false-positive ( $\mathrm{Li}$ et al. 2009). For database search and protein acceptance, the following criteria were imposed: three fragment ions per peptide and seven fragment ions per protein with at least one unique peptide per protein; within 10 and 20 parts per million (ppm) of the theoretical masses for precursor and fragment ions, respectively; full tryptic specificity with one missed cleavage; variable modifications of oxidation (methionine), deamidation (asparagine, glutamine), as well as static modification of carbamidomethylation (cysteine). The database search returned results for each injection until $4 \%$ of the identified proteins were false (random sequence). After all of the data were processed, a further requirement was made that, for acceptance, a protein must be identified in at least two of three replicate injections of the same sample. Absolute quantitation of identified peptides was achieved with the ion chromatographic peak areas of the three most intense tryptic peptides for each protein relative to that of the signal intensity of the three most intense ions for the internal standard (ADH). For each accepted protein, the relative standard deviation of the femtomole amount from the three replicate runs was calculated (Silva et al. 2006).

\section{Western blots}

Cell extracts from strain MJM01 (Cdc5-GFP, Lea1-protein A, Snu114-CBP), MJM02 (Brr2-GFP, Lea1-protein A, Snu114-CBP), and MJM03 (Spp42-GFP, Lea1-protein A, Snu114-CBP) were used for Western blots. Total proteins were separated by $4 \%-12 \%$ SDSPAGE and transferred to PVDF membrane. Western blots were carried out by using anti-GFP (SC-9996, Santa Cruz) with 800RD antirabbit IgG, anti-CBP (07-482, Millipore) with 680RD anti-mouse IgG, and detected on an Odyssey scanner (fluorescence).

\section{RNA and Northern blots}

Total RNA from purified complexes was resolved on an $8 \%$ polyacrylamide- $8 \mathrm{M}$ urea gel and the gel stained with SYBR Gold (Invitrogen). For Northern blotting, RNAs were transferred to Biotrans $(+)^{\mathrm{TM}}$ NYLON membranes by semidry electroblotting. snRNAs were detected with complementary, ${ }^{32} \mathrm{P}$-labeled oligonucleotides; the U6 probe spanned its exon-exon junction.

\section{Deep sequencing}

RNAseq libraries were generated as previously described (Ingolia et al. 2009) with the following modifications. Total RNA from each prep was subjected to alkaline hydrolysis followed by incubation with T4 polynucleotide kinase (NEB) in the absence of ATP to remove $2^{\prime}, 3^{\prime}$-cyclic and $3^{\prime}$ phosphate groups. Following denaturing gel electrophoresis, the 30 - to 80 -nt region was excised, and recovered RNAs were poly(A)-tailed and converted into libraries for deep sequencing on the Illumina GAII platform as previously described (Ingolia et al. 2009).

\section{RNAseq data analysis}

Raw 36-bp reads were searched for the poly(A) adapter sequence. If a run of six or more adenosines was detected, the sequence prior to the first A was excised and mapped to the $S$. pombe genome and transcriptome (Sanger Sept. 2011 version) with Bowtie (version 0.11.3). To avoid mapping to spurious locations in the genome, we only retained sequences that met the following criteria: (1) sequences 12 - to 15-nt-long had to map perfectly to a single location in the genome or transcriptome; (2) sequences 16- to 19-nt-long had to map perfectly to the genome or transcriptome; (3) sequences $\geq 20 \mathrm{nt}$ had to map to the genome or transcriptome with no more than one mismatch. If a sequence $\geq 16 \mathrm{nt}$ mapped to multiple locations, each location was allocated an equal share. The UCSC genome browser (http://genome.ucsc.edu/) was used for making numerous figures. All other analyses were performed with custom-built PERL scripts.

Quantitative analyses employed five classes of CDS mapping reads: (1) exonic $=$ reads mapping entirely inside an exon; (2) intronic $=$ reads mapping entirely inside an intron; (3) $5^{\prime} \mathrm{SS}=$ reads straddling a $5^{\prime}$ splice site; (4) $3^{\prime} \mathrm{SS}=$ reads straddling a $3^{\prime}$ splice site; and (5) EEJ = reads straddling an exon-exon junction. For correlation with Pol II occupancy and mRNA abundance, we summed the total reads of all five types for each gene. Peak calling in intergenic regions was performed by extending each intergenic position with $\geq 11$ tags in both directions until a position having no tag was encountered. Overlaps between peaks and annotated genes were performed in a strand-specific manner.

\section{SUPPLEMENTAL MATERIAL}

Supplemental material is available for this article.

\section{ACKNOWLEDGMENTS}

We thank D. Crawford and M. Lisbin for strain construction, J. Evans for mass spec analyses, M. Zapp and E. Kittler at the UMMS Deep Sequencing Core Laboratory for RNAseq, and A. Hoskins for critical reading of the manuscript. This work was supported by funding from HHMI, NIH RO1-GM53007 (M.J.M.) and NSF DBI-0850008 (Z.W.). M.J.M. is an HHMI Investigator.

Received June 27, 2013; accepted November 12, 2013.

\section{REFERENCES}

Abovich N, Liao XC, Rosbash M. 1994. The yeast MUD2 protein: An interaction with PRP11 defines a bridge between commitment complexes and U2 snRNP addition. Genes Dev 8: 843-854.

Agafonov DE, Deckert J, Wolf E, Odenwalder P, Bessonov S, Will CL, Urlaub H, Luhrmann R. 2011. Semiquantitative proteomic analysis of the human spliceosome via a novel two-dimensional gel electrophoresis method. Mol Cell Biol 31: 2667-2682.

Anokhina M, Bessonov S, Miao Z, Westhof E, Hartmuth K, Luhrmann R. 2013. RNA structure analysis of human spliceosomes reveals a compact $3 \mathrm{D}$ arrangement of snRNAs at the catalytic core. EMBO J 32: 2804-2818.

Bahler J, Wu JQ, Longtine MS, Shah NG, McKenzie A, Steever AB, Wach A, Philippsen P, Pringle JR. 1998. Heterologous modules for efficient and versatile PCR-based gene targeting in Schizosaccharomyces pombe. Yeast 14: 943-951. 
Barbosa I, Haque N, Fiorini F, Barrandon C, Tomasetto C, Blanchette M, Le Hir H. 2012. Human CWC22 escorts the helicase eIF4AIII to spliceosomes and promotes exon junction complex assembly. Nat Struct Mol Biol 19: 983-990.

Behrens SE, Tyc K, Kastner B, Reichelt J, Luhrmann R. 1993. Small nuclear ribonucleoprotein (RNP) U2 contains numerous additional proteins and has a bipartite RNP structure under splicing conditions. Mol Cell Biol 13: 307-319.

Bessonov S, Anokhina M, Will CL, Urlaub H, Luhrmann R. 2008. Isolation of an active step I spliceosome and composition of its RNP core. Nature 452: 846-850.

Bessonov S, Anokhina M, Krasauskas A, Golas MM, Sander B, Will CL, Urlaub H, Stark H, Luhrmann R. 2010. Characterization of purified human $\mathrm{B}^{\text {act }}$ spliceosomal complexes reveals compositional and morphological changes during spliceosome activation and first step catalysis. RNA 16: 2384-2403.

Boelens WW, Scherly DD, Beijer RPR, Jansen EJE, Dathan NAN, Mattaj IWI, van Venrooij WJW. 1991. A weak interaction between the $\mathrm{U}_{2} \mathrm{~A}^{\prime}$ protein and $\mathrm{U} 2$ snRNA helps to stabilize their complex with the U2B" protein. Nucleic Acids Res 19: 455-460.

Boon KL, Auchynnikava T, Edwalds-Gilbert G, Barrass JD, Droop AP, Dez C, Beggs JD. 2006. Yeast ntr1/spp382 mediates prp43 function in postspliceosomes. Mol Cell Biol 26: 6016-6023.

Brosi R, Gröning K, Behrens S, Luhrmann R, Krämer A. 1993a. Interaction of mammalian splicing factor SF3a with U2 snRNP and relation of its 60-kD subunit to yeast PRP9. Science 262: 102-105.

Brosi R, Hauri HP, Krämer A. 1993b. Separation of splicing factor SF3 into two components and purification of SF3a activity. J Biol Chem 268: $17640-17646$.

Caspary F. 1998. The yeast U2A'/U2B" complex is required for pre-spliceosome formation. EMBO J 17: 6348-6358.

Chen YIG, Moore RE, Ge HY, Young MK, Lee TD, Stevens SW. 2007. Proteomic analysis of in vivo-assembled pre-mRNA splicing complexes expands the catalog of participating factors. Nucleic Acids Res 35: 3928-3944.

Chen HC, Tseng CK, Tsai RT, Chung CS, Cheng SC. 2013. Link of NTR-mediated spliceosome disassembly with DEAH-box ATPases Prp2, Prp16, and Prp22. Mol Cell Biol 33: 514-525.

Coltri P, Effenberger K, Chalkley RJ, Burlingame AL, Jurica MS. 2011. Breaking up the C complex spliceosome shows stable association of proteins with the lariat intron intermediate. PLoS One 6: e19061.

Dziembowski A, Ventura A-P, Rutz B, Caspary F, Faux C, Halgand F, Laprévote O, Séraphin B. 2004. Proteomic analysis identifies a new complex required for nuclear pre-mRNA retention and splicing. EMBO J 23: 4847-4856.

Fabrizio P, Dannenberg J, Dube P, Kastner B, Stark H, Urlaub H, Luhrmann R. 2009. The evolutionarily conserved core design of the catalytic activation step of the yeast spliceosome. Mol Cell 36: 593-608.

Fourmann JB, Schmitzova J, Christian H, Urlaub H, Ficner R, Boon KL, Fabrizio P, Luhrmann R. 2013. Dissection of the factor requirements for spliceosome disassembly and the elucidation of its dissociation products using a purified splicing system. Genes Dev 27: 413-428.

Gozani O, Feld R, Reed R. 1996. Evidence that sequence-independent binding of highly conserved U2 snRNP proteins upstream of the branch site is required for assembly of spliceosomal complex A. Genes Dev 10: 233-243.

Grainger RJ, Barrass JD, Jacquier A, Rain JC, Beggs JD. 2009. Physical and genetic interactions of yeast Cwc21p, an ortholog of human SRm300/SRRM2, suggest a role at the catalytic center of the spliceosome. RNA 15: 2161-2173.

Hahn D, Beggs JD. 2010. Brr2p RNA helicase with a split personality: Insights into structure and function. Biochem Soc Trans 38: 11051109 .

Hodges PE, Beggs JD. 1994. RNA splicing: U2 fulfils a commitment. Curr Biol 4: 264-267.

Hoskins AA, Moore MJ. 2012. The spliceosome: A flexible, reversible macromolecular machine. Trends Biochem Sci 37: 179-188.
Huang T, Vilardell J, Query CC. 2002. Pre-spliceosome formation in S. pombe requires a stable complex of SF1-U $2 \mathrm{AF}^{59}-\mathrm{U} 2 \mathrm{AF}^{23}$. EMBO J 21: $5516-5526$.

Ilagan JO, Chalkley RJ, Burlingame AL, Jurica MS. 2013. Rearrangements within human spliceosomes captured after exon ligation. RNA 19: 400-412.

Ingolia NT, Ghaemmaghami S, Newman JRS, Weissman JS. 2009. Genome-wide analysis in vivo of translation with nucleotide resolution using ribosome profiling. Science 324: 218-223.

Jurica MS. 2008. Searching for a wrench to throw into the splicing machine. Nat Chem Biol 4: 3-6.

Jurica MS, Moore MJ. 2002. Capturing splicing complexes to study structure and mechanism. Methods 28: 336-345.

Jurica MS, Moore MJ. 2003. Pre-mRNA splicing. Mol Cell 12: 5-14.

Jurica MS, Sousa D, Moore MJ, Grigorieff N. 2004. Three-dimensional structure of $\mathrm{C}$ complex spliceosomes by electron microscopy. Nat Struct Mol Biol 11: 265-269.

Kim D-U, Hayles J, Kim D, Wood V, Park H-O, Won M, Yoo H-S, Duhig T, Nam M, Palmer G, et al. 2010. Analysis of a genomewide set of gene deletions in the fission yeast Schizosaccharomyces pombe. Nat Biotechnol 28: 617-623.

Krämer A, Grüter P, Gröning K, Kastner B. 1999. Combined biochemical and electron microscopic analyses reveal the architecture of the mammalian U2 snRNP. J Cell Biol 145: 1355-1368.

Laggerbauer B, Achsel T, Luhrmann R. 1998. The human U5-200kD DEXH-box protein unwinds U4/U6 RNA duplices in vitro. Proc Natl Acad Sci 95: 4188-4192.

Lardelli RM, Thompson JX, Yates JR, Stevens SW. 2010. Release of SF3 from the intron branchpoint activates the first step of pre-mRNA splicing. RNA 16: 516-528.

Li G-Z, Vissers JPC, Silva JC, Golick D, Gorenstein MV, Geromanos SJ. 2009. Database searching and accounting of multiplexed precursor and production spectra from the data independent analysis of simple and complex peptide mixtures. Proteomics 9: 1696-1719.

Li X, Zhang W, Xu T, Ramsey J, Zhang L, Hill R, Hansen KC, Hesselberth JR, Zhao R. 2013. Comprehensive in vivo RNA-binding site analyses reveal a role of Prp8 in spliceosomal assembly. Nucleic Acids Res 41: 3805-3818.

Lin P-C, Xu R-M. 2012. Structure and assembly of the SF3a splicing factor complex of U2 snRNP. EMBO J 31: 1579-1590.

Makarov EM. 2002. Small nuclear ribonucleoprotein remodeling during catalytic activation of the spliceosome. Science 298: 22052208.

Makarova OV, Makarov EM, Urlaub H, Will CL, Gentzel M, Wilm M, Luhrmann R. 2004. A subset of human 35S U5 proteins, including Prp19, function prior to catalytic step 1 of splicing. Nat Methods 23: 2381-2391.

McDonald WH, Ohi R, Smelkova N, Frendewey D, Gould KL. 1999. Myb-related fission yeast cdc5p is a component of a 40S snRNP-containing complex and is essential for pre-mRNA splicing. Mol Cell Biol 19: 5352-5362.

Ohi MD, Link AJ, Ren L, Jennings JL, McDonald WH, Gould KL. 2002. Proteomics analysis reveals stable multiprotein complexes in both fission and budding yeasts containing Myb-related Cdc5p/Cef1p, novel pre-mRNA splicing factors, and snRNAs. Mol Cell Biol 22: 2011-2024.

Ohi MD, Vander Kooi CW, Rosenberg JA, Ren L, Hirsch JP, Chazin WJ, Walz T, Gould KL. 2005. Structural and functional analysis of essential pre-mRNA splicing factor Prp19p. Mol Cell Biol 25: 451-460.

Ohi MD, Ren L, Wall JS, Gould KL, Walz T. 2007. Structural characterization of the fission yeast U5.U2/U6 spliceosome complex. Proc Natl Acad Sci 104: 3195-3200.

Puig O, Caspary F, Rigaut G, Rutz B, Bouveret E, Bragado-Nilsson E, Wilm M, Séraphin B. 2001. The tandem affinity purification (TAP) method: A general procedure of protein complex purification. Methods 24: 218-229.

Ren L, McLean JR, Hazbun TR, Fields S, Vander Kooi C, Ohi MD, Gould KL. 2011. Systematic two-hybrid and comparative proteomic 


\section{Chen et al.}

analyses reveal novel yeast pre-mRNA splicing factors connected to Prp19. PLoS One 6: e16719.

Rhind N, Chen Z, Yassour M, Thompson DA, Haas BJ, Habib N, Wapinski I, Roy S, Lin MF, Heiman DI, et al. 2011. Comparative functional genomics of the fission yeasts. Science 332: 930-936.

Scherly D, Boelens W, Dathan NA, van Venrooij WJ, Mattaj IW. 1990. Major determinants of the specificity of interaction between small nuclear ribonucleoproteins $\mathrm{U} 1 \mathrm{~A}$ and $\mathrm{U}_{2} \mathrm{~B}^{\prime \prime}$ and their cognate RNAs. Nat Methods 345: 502-506.

Schmidt C, Lenz C, Grote M, Luhrmann R, Urlaub H. 2010. Determination of protein stoichiometry within protein complexes using absolute quantification and multiple reaction monitoring. Anal Chem 82: 2784-2796.

Silva JC, Gorenstein MV, Li G-Z, Vissers JPC, Geromanos SJ. 2006. Absolute quantification of proteins by $\mathrm{LCMS}^{\mathrm{E}}$ : A virtue of parallel MS acquisition. Mol Cell Proteomics 5: 144-156.

Small EC, Leggett SR, Winans AA, Staley JP. 2006. The EF-G-like GTPase Snu114p regulates spliceosome dynamics mediated by Brr2p, a DExD/H box ATPase. Mol Cell 23: 389-399.

Steckelberg A-L, Boehm V, Gromadzka AM, Gehring NH. 2012. CWC22 connects pre-mRNA splicing and exon junction complex assembly. Cell Rep 2: 454-461.

Stevens SW. 2000. Analysis of low-abundance ribonucleoprotein particles from yeast by affinity chromatography and mass spectrometry microsequencing. Methods Enzymol 318: 385-398.

Tanaka N, Aronova A, Schwer B. 2007. Ntr1 activates the Prp43 helicase to trigger release of lariat-intron from the spliceosome. Genes Dev 21: 2312-2325.
Tang J, Abovich N, Rosbash M. 1996. Identification and characterization of a yeast gene encoding the $\mathrm{U} 2$ small nuclear ribonucleoprotein particle B" protein. Mol Cell Biol 16: 2787-2795.

Tasto JJ, Carnahan RH, McDonald WH, Gould KL. 2001. Vectors and gene targeting modules for tandem affinity purification in Schizosaccharomyces pombe. Yeast 18: 657-662.

Tsai RT, Tseng CK, Lee PJ, Chen HC, Fu RH, Chang KJ, Yeh FL, Cheng SC. 2007. Dynamic interactions of Ntr1-Ntr2 with Prp43 and with U5 govern the recruitment of Prp43 to mediate spliceosome disassembly. Mol Cell Biol 27: 8027-8037.

Wahl MC, Will CL, Luhrmann R. 2009. The spliceosome: Design principles of a dynamic RNP machine. Cell 136: 701-718.

Will CL, Luhrmann R. 2011. Spliceosome structure and function. Cold Spring Harb Perspect Biol 3: a003707.

Williams SG, Hall KB. 2011. Human U2B" protein binding to snRNA stemloops. Biophys Chem 159: 82-89.

Xu D, Nouraini S, Field D, Tang S-J, Friesen JD. 1996. An RNA-dependent ATPase associated with U2/U6 snRNAs in pre-mRNA splicing. Nat Methods 381: 709-713.

Yan D, Ares M. 1996. Invariant U2 RNA sequences bordering the branchpoint recognition region are essential for interaction with yeast SF3a and SF3b subunits. Mol Cell Biol 16: 818-828.

Yoshimoto R, Kataoka N, Okawa K, Ohno M. 2009. Isolation and characterization of post-splicing lariat-intron complexes. Nucleic Acids Res 37: 891-902.

Zhang X, Schwer B. 1997. Functional and physical interaction between the yeast splicing factors Slu7 and Prp18. Nucleic Acids Res 25: $2146-2152$. 

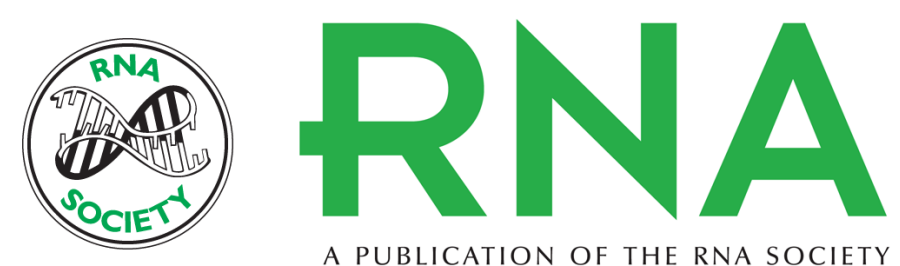

A PUBLICATION OF THE RNA SOCIETY

\section{Endogenous U2.U5.U6 snRNA complexes in S. pombe are intron lariat spliceosomes}

Weijun Chen, Hennady P. Shulha, Ami Ashar-Patel, et al.

RNA 2014 20: 308-320 originally published online January 17, 2014

Access the most recent version at doi:10.1261/rna.040980.113

\section{Supplemental http://rnajournal.cshlp.org/content/suppl/2014/01/06/rna.040980.113.DC1 Material}

References This article cites 64 articles, 34 of which can be accessed free at: http://rnajournal.cshlp.org/content/20/3/308.full.html\#ref-list-1

Creative This article is distributed exclusively by the RNA Society for the first 12 months after the Commons License full-issue publication date (see http://rnajournal.cshlp.org/site/misc/terms.xhtml). After 12 months, it is available under a Creative Commons License (Attribution-NonCommercial 3.0 Unported), as described at http://creativecommons.org/licenses/by-nc/3.0/.

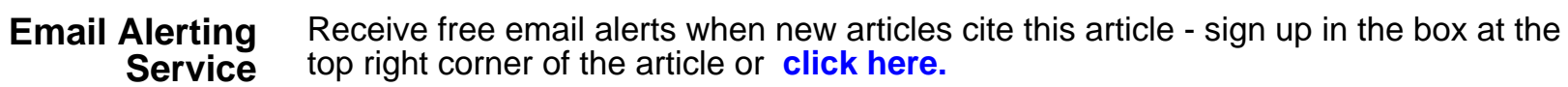

To subscribe to $R N A$ go to:

http://rnajournal.cshlp.org/subscriptions 